\title{
PHYTOCHEMICAL SCREENING, QUANTITATIVE ANALYSIS OF PRIMARY AND SECONDARY METABOLITES OF ACACIA ARABICA BARK
}

\author{
MAHENDRA A. DESHMUKH, MADHURI A. THENG \\ Department of Pharmacology, Sant Gadge Baba Amravati University, Amravati, Pin 442301, MS-Mharastra \\ Email: thengmadhuri7@gmail.com
}

Received: 25 Dec 2017, Revised and Accepted: 05 Feb 2018

\begin{abstract}
The study includes phytochemical screening and quantification of primary and secondary metabolites like chlorophyll, carbohydrates, protein, lipids, phenol, tannin and flavonoids from Acacia arabica bark. For these purpose aqueous extract of bark was prepared by "Soxhlet extraction method". The result of these study suggests that the Acacia arabica bark in which presence of primary and secondary metabolites.
\end{abstract}

Keywords: Phytochemical screening, Primary and Secondary metabolites, Acacia arabica bark

(C) 2018 The Authors. Published by Innovare Academic Sciences Pvt Ltd. This is an open access article under the CC BY license (http://creativecommons.org/licenses/by/4.0/) DOI: http://dx.doi.org/10.22159/ijcpr.2018v10i2.25889

\section{INTRODUCTION}

Since ancient times, people have been exploring the nature particularly medicinal plants in search of new drugs. Medicinal plants are used by $80 \%$ of the world population for their essential health needs. India is the birthplace of the renewed system of indigenous medicines such as Siddha, Ayurveda and Unani. Traditional systems of medicines are prepared from a single plant or combinations of more than one plant. This efficacy depends upon the current knowledge about taxonomic features of plant species, plant parts and biological property of medicinal plants which in turn depends upon the occurrence of primary and secondary metabolites [1]. Plant synthesize a wide range of chemical compounds which are classified based on their chemical class, biosynthetic origin and functional groups into primary and secondary metabolites. Primary metabolites directly involved in growth and development while secondary metabolites are not involved directly and they have been worked as biocatalysts. Primary metabolites are widely distributed in nature, occurring in one form or another in virtually all organisms. They are like chlorophyll, amino acids, nucleotides, carbohydrates etc. which have a key role in metabolic processes such as photosynthesis, respiration and nutrient assimilation. They are used as industrial raw materials and food additives. The drugs selected for this work were Acacia arabica these is important herbs are reported to have significant antibacterial, immunomodulatory and anti-inflammatory activities which are complementary to wound healing process. The growing popularity of natural and herbal medications, easy availability of raw materials, cost-effectiveness and the paucity of reported adverse reaction [2].

\section{MATERIALS AND METHODS}

\section{Materials}

The plants were selected on the basis of their phytochemical screening, quantitative analysis of primary and secondary metabolites and their medicinal uses reported in the literature. The herbs (Acacia arabica) were purchased from the local area of the city and authenticated by Taxonomist in the department of Botany, Shri Shivaji Science and Arts College, Chikhli. All other chemicals were of analytical grade and used without further purification.

\section{Preparation of the plant extracts}

The bark was washed under running tap water to remove the surface pollutants and the bark was air dried under shade. The powdered bark samples were subjected to successive extraction with chloroform, methanol and acetone using soxhlet apparatus. Fresh bark material was ground using distilled water and filtered and used as an aqueous extract. The extracts obtained using solvents were concentrated using rotary vacuum evaporator and then dried. The extract thus obtained was used for various analyses.

\section{Phytochemical screening of extracts}

Chloroform, methanol, aqueous and acetone extracts were used for preliminary phytochemical analyses using standard procedures. The following qualitative tests for both the metabolites were done as follows:

\section{a) Test for alkaloids}

Wagner's test: About $10 \mathrm{mg}$ of bark extract was taken and few drops of Wagner's reagent was added and the formation of a reddish brown precipitate indicates the presence of alkaloids.

\section{b) Test for flavonoids}

Shinoda test-10 mg of bark extract was added to a pinch of magnesium turnings and 1-2 drops of concentrated hydrochloric acid were added. Formation of pink color indicates the presence of Flavanoids.

Lead acetate test-10 mg of bark extract was taken and few drops of $10 \%$ lead acetate solution was added. Appearance of yellow colour precipitate indicates the presence of flavonoids.

\section{c) Test for phenols and tannins}

Lead acetate test: Ten mg of bark extract was taken and $0.5 \mathrm{ml}$ of $1 \%$ lead acetate solution was added and the formation of precipitate indicates the presence of tannins and phenolic compounds.

Ferric chloride test- $5 \mathrm{mg}$ of bark extract was taken and $0.5 \mathrm{ml}$ of $5 \%$ ferric chloride was added. The development of dark bluish black color indicates the presence of tannins. Sodium hydroxide test: Five $\mathrm{mg}$ of extract was dissolved in $0.5 \mathrm{ml}$ of $20 \%$ sulphuric acid solution. Followed by addition of few drops of aqueous sodium hydroxide solution, it turns blue which indicates the presence of phenols [3].

\section{d) Test for carbohydrates}

Fehling's test- $5 \mathrm{ml}$ of Fehling's solution was added to $0.5 \mathrm{mg}$ of bark extract and boiled in a water bath. The formation of yellow or red precipitate indicates the presence of reducing power.

Benedict's test $-5 \mathrm{ml}$ of Benedict's solution was added to $0.5 \mathrm{mg}$ of extract and boiled in a water bath. The appearance of red or yellow or green precipitate indicates the presence of reducing sugars.

\section{e) Test for saponins}

Honeycomb test- $0.5 \mathrm{mg}$ of bark extract was taken in a test tube and few drops of $5 \%$ sodium bicarbonate solution was added. The mixture was shaken vigorously and kept for $3 \mathrm{~min}$. Formation of honeycomb like froth shows the presence of saponins. 
Foam test- $0.5 \mathrm{mg}$ of extract was diluted with $20 \mathrm{ml}$ distilled water and shaken well in a graduated cylinder for $15 \mathrm{~min}$. The formation of foam to a length of $1 \mathrm{~cm}$ indicated the presence of saponins.

\section{e) Test for glycosides}

Glycoside test- $0.5 \mathrm{mg}$ of bark extract was dissolved in $1 \mathrm{ml}$ of water and then aqueous $\mathrm{NaOH}$ solution was added.

Formation of yellow color indicates the presence of glycosides.

\section{f) Test for protein and amino acids}

Biuret test-To $0.5 \mathrm{mg}$ of extract equal volume of $40 \% \mathrm{NaOH}$ solution and two drops of $1 \%$ copper sulphate solution was added. The appearance of violet colour indicates the presence of protein.

Ninhydrin test-About $0.5 \mathrm{mg}$ of extract was taken and 2 drops of freshly prepared $0.2 \%$ ninhydrin reagent were added and heated. The appearance of pink or purple colour indicates the presence of proteins, peptides or amino acids.

\section{g) Test for anthraquinone}

Borntragers test-About $0.5 \mathrm{gm}$ of the bark extract was taken into a dry test tube and $5 \mathrm{ml}$ of chloroform was added and shaken for 5 min. The extract was filtered and the filtrate was shaken with an equal volume of $10 \%$ ammonia solution. A pink violet or red colour in the lower layer indicates the presence of anthraquinone.

\section{Quantitative determination of primary metabolites}

\section{Determination of carbohydrate}

$100 \mathrm{mg}$ of extract bark was hydrolysed in a boiling tube with $5 \mathrm{ml}$ of $2.5 \mathrm{~N} \mathrm{HCl}$ in a boiling water bath for a period of $3 \mathrm{~h}$. It was cooled to room temperature and solid sodium carbonate was added until effervescence ceases. The contents were centrifuged and the supernatant was made to $100 \mathrm{ml}$ using distilled water. From this 0.2 $\mathrm{ml}$ of sample was pipetted out and made up the volume to $1 \mathrm{ml}$ with distilled water. Then $1.0 \mathrm{ml}$ of phenol reagent was added followed by $5.0 \mathrm{ml}$ of sulphuric acid. The tubes were kept at $25-30{ }^{\circ} \mathrm{C}$ for 20 min. The absorbance was read at $490 \mathrm{~nm}$. [4].

\section{Determination of protein}

The dried extract bark samples was extracted by stirring with $50 \mathrm{ml}$ of $50 \%$ methanol $(1: 5 \mathrm{w} / \mathrm{v})$ at $25{ }^{\circ} \mathrm{C}$ for $24 \mathrm{~h}$ and centrifuged at $7,000 \mathrm{rpm}$ for $10 \mathrm{~min} .0 .2 \mathrm{ml}$ of extract was pipette out and the volume was made to $1.0 \mathrm{ml}$ with distilled water. $5.0 \mathrm{ml}$ of alkaline copper reagent was added to all the tubes and allowed it to stand for $10 \mathrm{~min}$. Then $0.5 \mathrm{ml}$ of Folin's Ciocalteau reagent was added and incubated in dark for $30 \mathrm{~min}$. The intensity of the colour developed read at $660 \mathrm{~nm}$.

\section{Quantitative determination of secondary metabolites Determination of total phenolics and tannins}

The total phenolic content was determined according to the method described by 25 . Ten microlitre aliquots of the extracts $(2 \mathrm{mg} / 2 \mathrm{ml})$ was taken in test tubes and made up to the volume of $1 \mathrm{ml}$ with distilled water. Then $0.5 \mathrm{ml}$ of Folin-Ciocalteu phenol reagent (1:1 with water) and $2.5 \mathrm{ml}$ of sodium carbonate solution (20\%) were added sequentially in each tube. Soon after vortexing the reaction mixture, the test tubes were placed in dark for $40 \mathrm{~min}$ and the absorbance was recorded at $725 \mathrm{~nm}$ against the reagent blank. The analysis was performed in triplicate and the results were expressed as tannic acid equivalents. Using the same extracts the tannins was estimated after treatment with polyvinyl polypyrrolidone (PVPP). One hundred milligrams of PVPP was placed in a test tube and to this $1 \mathrm{ml}$ distilled water and then $1 \mathrm{ml}$ of the sample extracts were added. The contents were vortexed and kept in the test tube at $4{ }^{\circ} \mathrm{C}$ for $4 \mathrm{~h}$. Then it was centrifuged (3000 rpm for $10 \mathrm{~min}$ at room temperature) and the supernatant was collected. This supernatant has only simple phenolics other than tannins (the tannins would have been precipitated along with the PVPP). The phenolic content of the supernatant was measured as mentioned by 25 and expressed as the content of nontannin phenolics (tannic acid equivalents) on a dry matter basis. From the above results, the tannin content of the sample was calculated as follows: Tannin (\%) = Total phenolics (\%)-Non-tannin phenolics (\%)

\section{Determination of total flavonoid content}

The flavonoid content was determined by the use of a slightly modified colorimetry method described previously by 26 . A $0.5 \mathrm{ml}$ aliquot of appropriately $(2 \mathrm{mg} / 2 \mathrm{ml})$ diluted sample solution was mixed with $2 \mathrm{ml}$ of distilled water and subsequently with $0.15 \mathrm{ml}$ of $5 \%$ NaNO2 solution. After $6 \mathrm{~min}, 0.15 \mathrm{ml}$ of $10 \% \mathrm{AlCl} 3$ solution was added and allowed to stand for $6 \mathrm{~min}$, and then $2 \mathrm{ml}$ of $4 \% \mathrm{NaOH}$ solution was added to the mixture. Immediately, water was added to bring the final volume to $5 \mathrm{ml}$, and then the mixture was thoroughly mixed and allowed to stand for another $15 \mathrm{~min}$. The absorbance of the mixture was determined at 510 $\mathrm{nm}$ versus water blank. The analysis was performed in triplicate and the results were expressed as rutin equivalent [5].

\section{Statistical analysis}

All the analyses were performed in triplicate and the results were statistically analyzed and expressed as mean $(n=3) \pm$ standard deviation (SD).

\section{RESULTS AND DISCUSSION}

The phytochemical analysis is of supreme importance in identifying new source of therapeutically and industrially valuable compounds having medicinal plants have been chemically investigated. In the present investigation, primary and secondary metabolites were qualitatively and quantitatively analysed using Acacia arabica bark. The results are presented in table 1 and 2 and fig. 1.

Table 1: Preliminary phytochemical screening of acacia arabica bark

\begin{tabular}{|c|c|c|c|c|c|}
\hline \multirow[t]{2}{*}{ Plant constituent } & \multicolumn{5}{|l|}{ Extracts } \\
\hline & $\begin{array}{l}\text { Chloroform } \\
\text { extract }\end{array}$ & $\begin{array}{l}\text { Methanol } \\
\text { extract }\end{array}$ & $\begin{array}{l}\text { Aqueous } \\
\text { extract }\end{array}$ & $\begin{array}{l}\text { Acetone } \\
\text { extract }\end{array}$ & Name of test \\
\hline 1) Alkaloid & - & - & - & - & Wagners test \\
\hline 2) Flavonoids & - & + & - & + & Shinoda, Lead Acetate test \\
\hline 3) Phenolic and Tannins & - & + & + & - & $\begin{array}{l}\text { Lead acetate test, Ferric } \\
\text { chloride test }\end{array}$ \\
\hline 4) Carbohydrates & - & + & - & - & Fehlings test, Benedict test \\
\hline 5) Saponin & - & - & + & + & Honey comb test, Foam test \\
\hline 6) Glycoside & - & + & - & - & Glycosides test \\
\hline 7) Protein and Amino acid & + & + & + & - & Biuret test, Ninhydrin test \\
\hline 8) Anthraquinone & + & + & + & - & Borntragers test \\
\hline
\end{tabular}

Table 2: Quantification of primary metabolites of Acacia arabica bark

\begin{tabular}{ll}
\hline Carbohydrates & $155.61 \pm 25.62$ \\
Amino acids & $8.08 \pm 0.03$ \\
Protein & $104.6 \pm 3.78$ \\
Lipids & $6.04 \pm 0.002$ \\
\hline
\end{tabular}

Values are mean of four independent analysis $\pm \operatorname{SD}(n=4)$. 


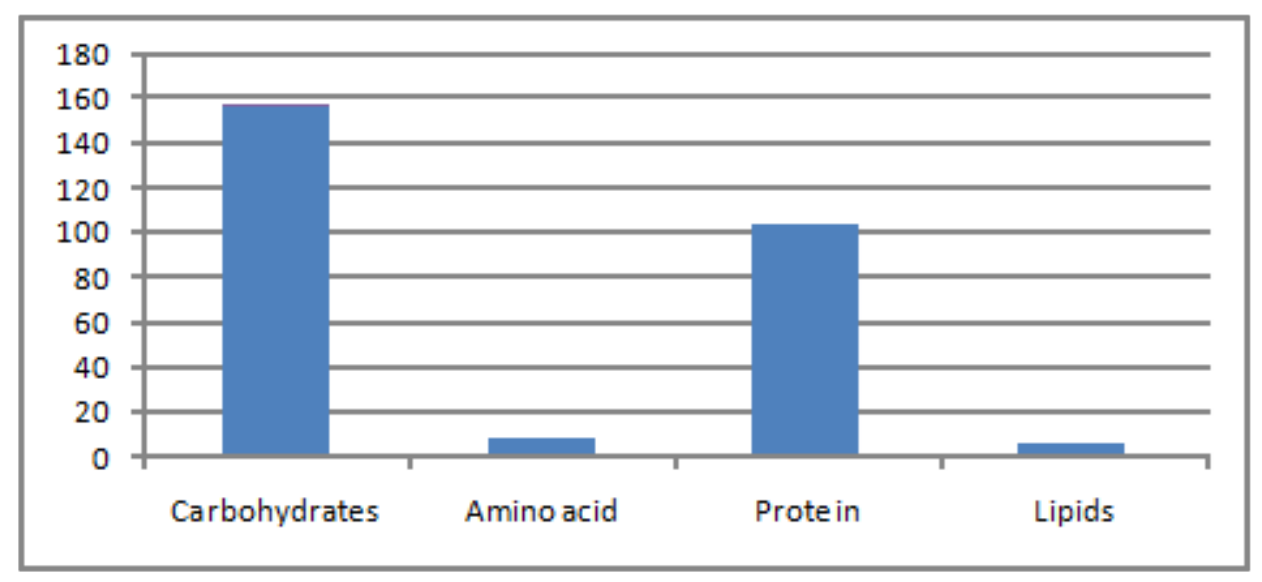

Fig. 1:

\section{DISCUSSION}

From the above remarks, it can be concluded that all the parameters of the Acacia arabica bark extract in which presence of phytochemical components of carbohydrate, protein, lipids, phenols, flavonoids and tannins.

\section{CONCLUSION}

Thus the result obtained in the present study indicates Acacia arabica bark extract have the potential to act as a source of useful drugs because of presence of various phytochemical components such as carbohydrate, protein, lipids, phenols, flavonoids and tannins. The results are very much encouraging but scientific validation is necessary before being put in to practis.

\section{AUTHORS CONTRIBUTIONS}

All the author have contributed equally

\section{CONFLICT OF INTERESTS}

Declared none

\section{REFERENCES}

1. Vinoth S, Rajeshkanna P, Gurusaravanan P, Jayabalan N. Evaluation of phytochemical, antimicrobial and GC-MS analysis of extracts of Indigofera trita L. f. Spp. Subulata (Vahl ex poir). Int J Agric Res 2011;6:358-67.

2. Noble RI. The discovery of Vinca alkaloids chemotherapeutic agents against cancer. Biochem Cell Biol 1990;68:1544-51.

3. Lingarao M, Savithramma N. Quantification of primary and secondary metabolites of Svensonia hyderobadensis-a rare medicinal plant. Int J Pharm Pharm Sci 2012;4:519-21.

4. Nandagopal S, Ranjitha Kumari BD. Phytochemical and antibacterial studies of Chicory (Cichorium intybus L.)-a multipurpose medicinal plant. Adv Biol Res 2007;1:17-21.
5. Sharma MC, Sharma S. Phytochemical screening of methanolic extract and antimicrobial activity of Eclipta alba and Morinda Citrifolia L., Middle East J Sci Res Plants 2010;6:445-9.

6. Gupta C, Garg AP, Gupta S. Antimicrobial and phytochemical studies of fresh ripe pulp and dried unripe pulp of Mangifera indica (AMCHUR). Middle-East J Sci Res 2010;5:75-80.

7. Boopathi CA, Sivakumar R. Phytochemical screening studies on the leaves and stem of Andrographis neesianan wight-an endemic medicinal plants from India. World Appl Sci J 2011;49;56-59.

8. Michael Bennett. Some dressings are classed as pharmaceuticals to wound care and how to select the wound dressing. Clin Pharma 2010;2:363-5.

9. Moon RS, Shrikhande R, Purohit N. Formulation and study of burn wound effect of herbal creams advance in pharmacology and toxicology. Indian J Pharm Sci 2007;8:1-25.

10. Rajvaidhya Sourbh, GK Signh. A review on Acacia arabica in Indian medicinal plants. Int J Pharm Sci Res 2012;7:1995-2005.

11. Rawat S, Singh R, Thakur P, Kaur S Semwal. A wound healing agents from medicinal plants a review. Asian Pacific J Trop Biomed 2012;2:1910-7.

12. Sapna Malviya. Medicinal attributes of Acacia arabica linn a comprehensive review on ethophamacological claims. International Journal of Pharmacy and life sciences. 2011;2:830-37.

13. Middleton E, Kandaswami C. The impact of plant flavonoids on mammalian biology: implications for immunity, inflammation and cancer. In: Harborne JB. Ed. The Flavonoids. Chapman and Hall, London; 1994. p. 619-52.

14. Chung KT, Wong TY, Wei CL, Huang YW, Lin Y. Tannins and human health: a review. Crit Rev Food Sci Nutr 1998;6:421-64.

15. Hindumathy CK. In vitro study of antibacterial activity of cymbopogon citratus, world academy of science. Eng Technol 2011;5:189-93. 